\title{
SIGHTINGS OF FRANCISCANA DOLPHINS (PONTOPORIA BLAINVILLEI) OFF ESPÍRITO SANTO, BRAZIL
}

\author{
Ignacio B. Moreno ${ }^{1,2, *}$, Cristiane C. A. Martins ${ }^{3}$, Artur Andriolo ${ }^{4}$ and Márcia H. Engel ${ }^{3}$
}

The franciscana dolphin, Pontoporia blainvillei, is distributed in coastal waters of South America, from Itaúnas $\left(18^{\circ} 25^{\prime} \mathrm{S}\right.$; $\left.030^{\circ} 42^{\prime} \mathrm{W}\right)$, Espírito Santo State (ES), Brazil (Siciliano et al.,

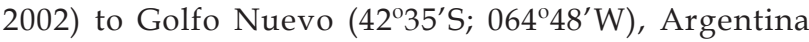
(Crespo et al., 1998). Two populations have been recognized based on morphology and genetics (e.g. Pinedo, 1991; Secchi et al., 1998). Discontinuities in franciscana distribution have been observed between Regência $\left(19^{\circ} 40^{\prime} \mathrm{S}\right)$ and Barra de Itabapoana $\left(21^{\circ} 18^{\prime} \mathrm{S}\right)$ and between Macaé $\left(22^{\circ} 25^{\prime} \mathrm{S}\right)$ and Ubatuba $\left(23^{\circ} 18^{\prime} \mathrm{S}\right)$ (Siciliano et al., 2002). However, more recently Azevedo et al. (2002) reported the collection of franciscana specimens in the area of Ilha Grande bay ( $c a .23^{\circ} 10^{\prime}-22^{\circ} 59^{\prime} S$ ) and northern São Paulo State $\left(23^{\circ} 22^{\prime} S\right)$. These gaps split the species into two, possibly small, isolated populations in northern Rio de Janeiro (RJ) and Espírito Santo (ES). The reason for these hiatuses is unclear, but Siciliano et al. (2002) proposed that water transparency and depth were among the possible causes.

This note reports on sightings of franciscana dolphins in northern Espírito Santo (Figure 1). They occurred on 06 September 2003 during an aerial survey to estimate humpback whale (Megaptera novaeangliae) abundance and distribution in Brazilian waters. The aircraft was adapted with one bubble window on each side, flown at a height of $152 \mathrm{~m}$ with a constant relative speed of approximately 90 knots. The sea state was 3 in the Beaufort scale, the visibility was good and the water was turbid. At 12:44pm one individual of $P$. blainvillei was observed at $19^{\circ} 40^{\prime} 16.98^{\prime \prime} S$; $039^{\circ} 44^{\prime} 38.17^{\prime \prime} \mathrm{W}$ and few seconds later another group with four animals was sighted at $19^{\circ} 40^{\prime} 17.70^{\prime \prime} \mathrm{S} ; 039^{\circ} 43^{\prime} 43.40^{\prime \prime} \mathrm{W}$ on the same side of the plane by the same observer. Both sightings were made on effort at $217 \mathrm{~m}$ away from the trackline. In order to resight the groups, the transect line was abandoned and the aircraft returned to the first sighting position. Three other groups, one of ten and two of three animals, were observed at $19^{\circ} 40^{\prime} 03.60^{\prime \prime}$; $039^{\circ} 43^{\prime} 46.69^{\prime \prime} \mathrm{W}$. However, some individuals could belong to the first two groups sighted before. No apparent reaction to the airplane and no calves were observed. The sightings were made about $6 \mathrm{~nm}$ from shore, approximately to the $20 \mathrm{~m}$ isobath and were near the southern range of the supposed isolated population of northern ES. The sighting area is very close to the Doce River mouth and is strongly influenced by its turbid waters. This is in agreement with the overall description of habitat preferences for this species (Bordino et al., 2002; Siciliano et al., 2002). Sightings of franciscana throughout most of its range are uncommon, possibly due to its small body

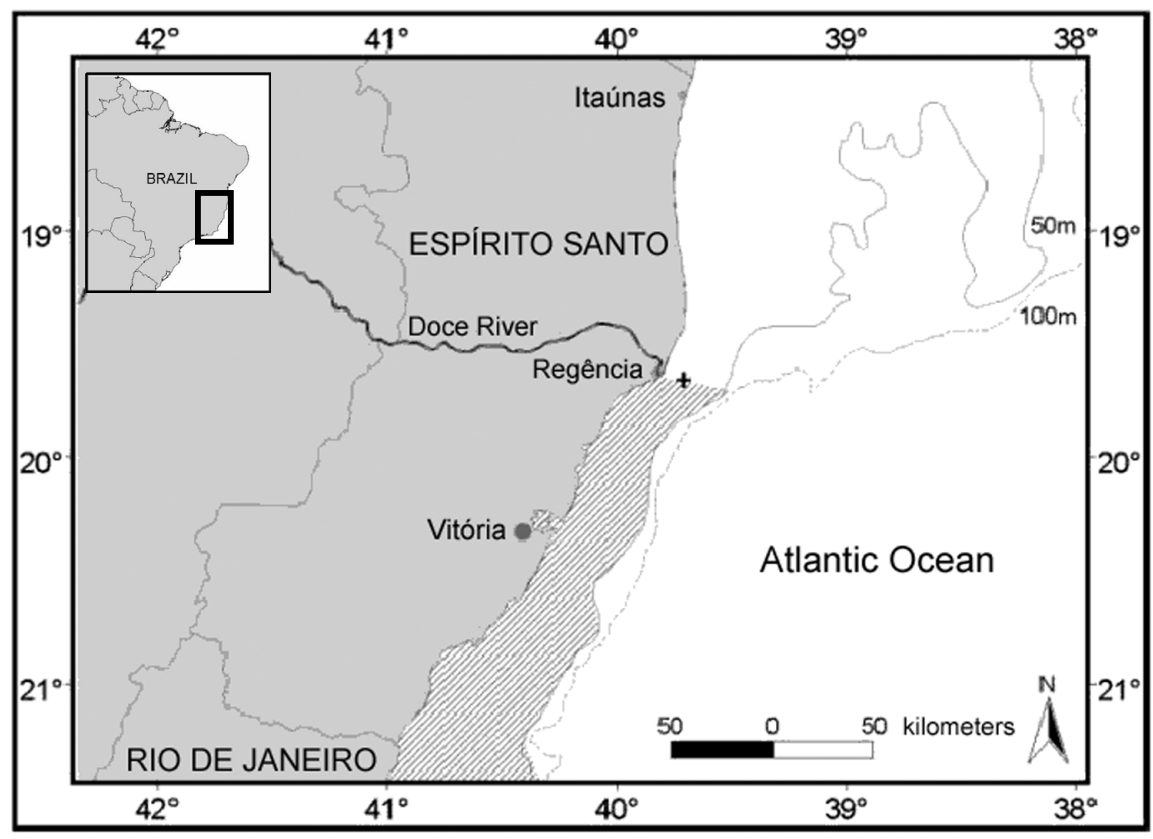

Figure 1. Sightings locations (+) of Pontoporia blainvillei in Espírito Santo State. The shaded area corresponds to the northern hiatus in the distribution of the franciscana, proposed by Siciliano et al. (2002).

\footnotetext{
${ }^{1}$ Grupo de Estudos de Mamíferos Aquáticos do Rio Grande do Sul (GEMARS). Rua Felipe Neri, 382/203, Porto Alegre, RS, 90440-150, Brazil.

${ }^{2}$ Centro de Estudos Costeiros, Limnológicos e Marinhos (CECLIMAR - UFRGS). Av. Tramandaí, 976, Imbé, RS, 90690-000, Brazil.

${ }_{3}^{3}$ Projeto Baleia Jubarte/Instituto Baleia Jubarte. Praia do Kitongo, s/n, Caravelas, BA, 45900-000, Brazil.

${ }^{4}$ Universidade Federal de Juiz de Fora, Instituto de Ciências Biológicas, Departamento de Zoologia. Juiz de Fora, MG, 36036-330, Brazil.

* Corresponding author, e-mail: igmoreno@terra.com.br.
} 
size, the turbidity of the water and the species tendency to avoid engine-powered boats (Crespo et al., 2002). Although franciscana group size tends to be small, ranging from 1 to 6 animals (Bordino et al., 1999; Secchi et al., 2001), groups of 10 to 17 individuals have been recorded throughout the species range (Crespo et al., 1998; Bastida et al., 2000; Flores et al., 2000; Di Beneditto et al., 2001). Franciscanas are systematically seen only in few areas, namely the Bahia Anegada, in Argentina (Bordino et al., 1999) and Baía da Babitonga, in Brazil (Bordino et al., 2002). This is the first sightings record of $P$. blainvillei off Espírito Santo. The use of an airplane at low speed and adapted with bubble windows seems to be feasible to conduct surveys since in the present study franciscanas were easily observed and identified with confidence even in turbid waters.

The sightings reported here were seen near the southern range of the population of northern ES. In this area, to date, very few strandings or incidental captures have been recorded ( $\mathrm{n}=14$, from 1984 to 1994, Siciliano et al., 2002). More recently, a non-systematic study carried out from 1994 to 2001 along the ES coast failed to record any franciscana carcass (Freitas Netto and Barbosa, 2003). Despite the scarcity of records between 1984 and 1994 and the absolute lack of records in the last nine years (1994 to 2003), the opportunistic sightings reported in this note raises the issue that this potentially isolated population deserves special attention for research as virtually nothing is known about its biology and conservation status. Even though interactions with fishing activities do not seem to occur in large scale, other sources of potentially harmful anthropogenic activities are increasing in the region, in particular cargo ship traffic and oil and gas exploitation. Ramos et al. (2002) recommended to consider franciscanas from northern Espírito Santo as a discrete population for management purpose.

\section{Acknowledgements}

The authors would like to thank the pilots Alexandre Masulo and Fernando Moura. We also thank the logistic support of Abrolhos Turismo and AVS Táxi Aéreo. We wish to thank to Daniel Danilewicz and Eduardo Secchi who kindly reviewed the manuscript and made useful comments to improve the text. Nélio B. Barros revised the last version of the manuscript. This study was financially supported by Aracruz Celulose. This short communication is GEMARS contribution number 14 .

\section{References}

Azevedo, A.F., Fragoso, A.B., Lailson-Brito, J. and Cunha, H.A. (2002) Records of the franciscana (Pontoporia blainvillei) in the Southwestern Rio de Janeiro and Northernmost São Paulo State coast - Brazil. The Latin American Journal of Aquatic Mammals, 1(1): 191-192.

Bastida, R., Rodríguez, D. and Morón, S. (2000) Avistajes costeros y tamaño grupal de Pontoporia blainvillei en el sudeste de la provincia de Buenos Aires (Argentina). Pp.51-54 in: Report of the Third Workshop for Coordinated Research and
Conservation of the Franciscana Dolphin (Pontoporia blainvillei) in the Southwestern Atlantic, UNEP/CMS, 112p. [Available through UNEP/CSM Secretariat, Martin Luther King St.8, 53175, Bonn, Germany. http://wwww.wcmc.org.uk/cms]

Bordino, P., Thompson, G. and Iñíguez, M. (1999) Ecology and behavior of the franciscana (Pontoporia blainvillei) in Bahía Anegada, Argentina. Journal of Cetacean Research and Management 1(2): 213-22.

Bordino, P., Siciliano, S., Bastida, R. and Cremer, M. (2002) Report of the working group on distribution and behaviour. The Latin American Journal of Aquatic Mammals, 1(1): 21-23.

Crespo, E.A., Harris, G. and González, R. (1998) Group size and distributional range of the franciscana, Pontoporia blainvillei. Marine Mammal Science 14(4): 845-9.

Crespo, E., Secchi, E.R., Dalla-Rosa, L. Kinas, P., Danilewicz, D and Bordino, P. (2002) Report of the working group on abundance estimates. The Latin American Journal of Aquatic Mammals, 1(1): 65-66.

Di Beneditto, A.P., Ramos, R. and Lima, N.R.W. (2001) Sightings of Pontoporia blainvillei (Gervais \& D'Orbigny, 1844) and Sotalia fluviatilis (Gervais, 1853) (Cetacea) in South-eastern Brazil. Brazilian Archives of Biology and Technology, 44(3): 291-296.

Flores, P.A.C., Sousa-Lima, R.S and Siqueira, G.S. (2000) Avistagens de franciscana (Pontoporia blainvillei) na Baía Norte, Santa Catarina, Sul do Brasil. Pp.71-74 in: Report of the Third Workshop for Coordinated Research and Conservation of the Franciscana Dolphin (Pontoporia blainvillei) in the Southwestern Atlantic, UNEP/CMS, 112p. [Available through UNEP/CSM Secretariat, Martin Luther King St. 8, 53175, Bonn, Germany. http:/ / wwww.wcmc.org.uk/cms].

Freitas Netto, R.F. and Barbosa, L.A. (2003) Cetaceans and fishery interactions along the Espírito Santo State, Southeastern Brazil during 1994-2001. The Latin American Journal of Aquatic Mammals, 2(1): 57-60.

Ott, P.H., Secchi, E.R., Moreno, I.B., Danilewicz, D., Crespo, E.A, Bordino, P., Ramos, R., Di Beneditto, AP., Bertozzi, C., Bastida, R., Zanelatto, R.C., Perez, J.E. and Kinas, P.G. (2002) Report of the working group on fishery interactions. The Latin American Journal of Aquatic Mammals, 1(1): 55-64.

Pinedo, M.C. (1991) Development and variation of the franciscana Pontoporia blainvillei. Ph.D. Thesis, University of California, Santa Cruz.

Ramos, R.M.A, Di Beneditto, A.P., Siciliano, S., Santos, M.C., Zerbini, A.N., Bertozzi, C., Vicente, A., Zampirolli, E., Alvarenga, F.S. and Lima, N.R.W. (2002) Morphology of the franciscana (Pontoporia blainvillei) off Southeastern Brazil: sexual dimorphism, growth and geographic variation. The Latin American Journal of Aquatic Mammals, 1(1): 129-144.

Secchi, E.R., Wang, J.Y., Murray, B., Rocha-Campos, C. and White, B.N. (1998) Population differentiation in the franciscana (Pontoporia blainvillei) from two geographic locations in Brazil as determined from mitochondrial DNA control region sequences. Canadian Journal of Zoology, 76: 1622-1627.

Secchi, E.R., Ott, P.H., Crespo, E.A., Kinas, P.G., Pedraza, S.N. and Bordino, P. (2001) A first estimate of franciscana (Pontoporia blainvillei) abundance off southern Brazil. Journal of Cetacean Research and Management 3: 95-100.

Siciliano, S., Di Beneditto, A.P. and Ramos, R. (2002) A toninha, Pontoporia blainvillei (Gervais \& d'Orbigny, 1844) (Mammalia, Cetacea, Pontoporiidae), nos Estados do Rio de Janeiro e Espírito Santo, costa sudeste do Brasil: caracterização dos hábitats e possíveis fatores de isolamento das populações. Boletim do Museu Nacional, Nova Série, Zoologia. 146: 1-15.

Received 1 December 2003. Accepted 10 December 2003. 